ISSN 1461-9571

VOLUME

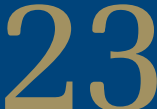

ISSUE 2

\title{
European
}

2020

\section{Journal of Archaeology}
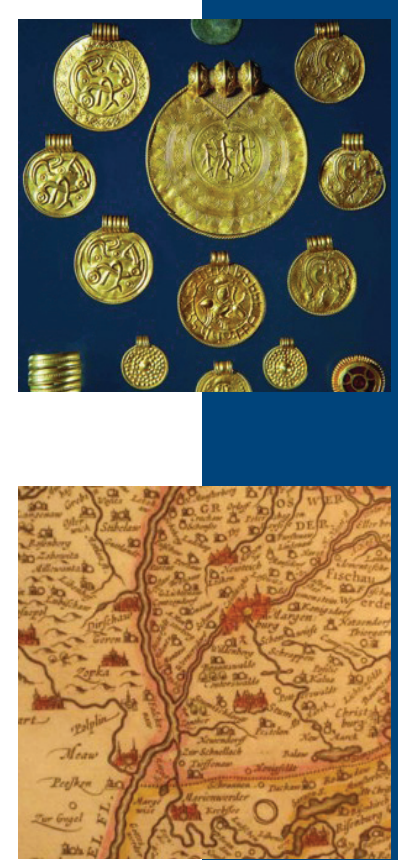

\begin{tabular}{l|l} 
E & $\begin{array}{l}\text { European Association } \\
\text { A }\end{array}$ \\
A & of Archaeologists
\end{tabular}

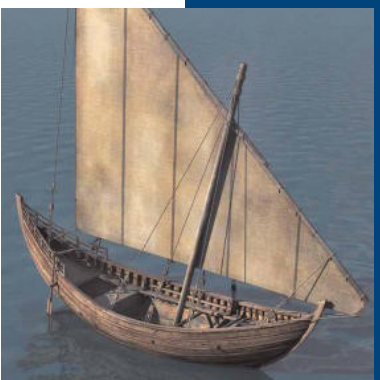




\section{European Journal of Archaeology}

Editor

Catherine J. Frieman, Australian National University, Australia

Deputy Editor

Zena Kamash, Royal Holloway, University of London, UK

Reviews Editor

Marta Díaz-Guardamino, Durham University, UK

Assistant Reviews Editor

Maria Relaki, Open University and University of Sheffield, UK

Editorial Board

Marta Díaz-Guardamino, Durham University, UK

Ekaterina Dolbunova, The State Hermitage Museum, Russian Federation

Georg Haggren, University of Helsinki, Finland

Daniela Hofmann, Hamburg University, Germany

John H. Jameson, U.S. National Park Service (Ret.), USA

Joern Lang, University of Leipzig, Germany

Clara Masriera-Esquerra, Autonomous University of Barcelona, Spain

Eileen Murphy, Queen's University, Belfast, Northern Ireland

Maria Relaki, Open University and University of Sheffield, UK

EJA Advisory Board

Eszter Bánffy, German Archaeological Institute, Germany

Phillippe Della Casa, University of Zurich, Switzerland

Zbigniew Kobyliński, Cardinal Stefan Wyszyński University in Warsaw, Poland

Kristian Kristiansen, Göteborg University, Sweden

Marinella Pasquinucci, University of Pisa, Italy

Gustavo Politis, National University of the Center of the Buenos Aires Province, Argentina

Christopher Prescott, University of Oslo, Norway

Douglas Price, University of Wisconsin, USA

Mehmet Özdoğan, University of Istanbul, Turkey

Robin Skeates, Durham University, UK

Editorial Assistant

Madeleine Hummler, University of York, UK

Aims and Scope

The European Journal of Archaeology is the international, peer-reviewed journal of the European Association of Archaeologists aiming to publish the best new archaeological research undertaken in and around Europe.

Articles cover a wealth of topics including major reviews of the prehistoric and historic archaeology of Europe and neighbouring regions; reports on key archaeological discoveries set within a European context; cutting-edge research and debates on sciencebased archaeology, archaeological method and theory, public archaeology and the history of archaeology; and interviews reflecting upon the life and work of significant European archaeologists. All articles are published with short, accessible abstracts in English, French and German.

\section{Submission procedure}

All articles must be submitted online at ejarch.edmgr.com

Detailed Instructions for Authors can be found at

https://www.cambridge.org/core/journals/european-journal-of-archaeology/information/instructions-contributors

Style

British spelling (as given in the Oxford English Dictionary) is used (e.g. ize not ise). For more information please consult the Instructions for Authors.

\section{Referencing}

The Author-Date System should be used for referencing in order to minimize the number of footnotes or endnotes. References in the text should be made within parentheses and include the surname of the author (unless the author already appears within the same paragraph), the publication date of the work and, where necessary, the page reference. Contributions should be followed by an alphabetical list of Works Cited, comprising only those sources actually cited in the text.

\section{Open Access}

The European Journal of Archaeology supports Open Access through Gold and Green options. More information can be found at https://www.cambridge.org/core/services/open-access-policies.

Abstracting and indexing services

The European Journal of Archaeology is indexed by: Abstracts in Anthropology, Anthropological Index Online, the Arts and Humanities Citation Index, Ecology Abstracts, Environment Abstracts (Meta), Environmental Sciences and Pollution Management, SCOPUS.

The European Journal of Archaeology is published by Cambridge University Press on behalf of the European Association of Archaeologists. The journal is included in the Cambridge Core service and can be found at https://www.cambridge.org/core/ journals/european-journal-of-archaeology.

(c) European Association of Archaeologists. All rights reserved. No part of this publication may be reproduced, in any form or by any means, electronic, photocopy or otherwise, without permission in writing from Cambridge University Press (https://www. cambridge.org/core/journals/european-journal-of-archaeology/information/request-permissions). Permission to copy (for users in the USA) is available from Copyright Clearance Center, http://www.copyright.com, email: info@copyright.com.

This journal has been printed on FSC-certified paper and cover board. FSC is an independent, non-governmental, not-for-profit organization established to promote the responsible management of the world's forests. Please see www.fsc.org for information.

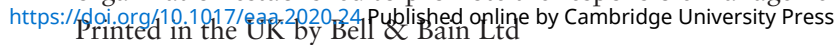




\section{European Journal of Archaeology}

Volume 23, Number 2, 2020

\section{Contents}

\section{Editorial}

Catherine J. Frieman....

\section{Articles}

Livija Ivanovaite, Kamil Serwatka, Christian Steven Hoggard, Florian Sauer and Felix Riede - All these Fantastic Cultures? Research History and Regionalization in the Late Palaeolithic Tanged Point Cultures of Eastern Europe

Courtney Nimura, Peter Skoglund and Richard Bradley - Navigating Inland:

Bronze Age Watercraft and the Lakes of Southern Sweden

Christian Løchsen Rødsrud - Burial Mounds, Ard Marks, and Memory: A Case

Study from the Early Iron Age at Bamble, Telemark, Norway.....

Henry Chapman, Roy van Beek, Ben Gearey, Ben Jennings, David Smith,

Nina Helt Nielsen and Zena Zein Elabdin - Bog Bodies in Context: Developing a

Best Practice Approach

Uroš Košir - When Violins Fell Silent: Archaeological Traces of Mass Executions

of Romani People in Slovenia.

Andres S. Dobat, Pieterjan Deckers, Stijn Heeren, Michael Lewis, Suzie Thomas and Anna Wessman - Towards a Cooperative Approach to Hobby Metal Detecting: The European Public Finds Recording Network (EPFRN) Vision Statement

\section{Reviews}

Anne Teather, Peter Topping and Jon Baczkowski, eds. Mining and Quarrying in Neolithic Europe: A Social Perspective

Reviewed by Emma Wager

Lise Bender Jørgensen, Joanna Sofaer and Marie Louise Stig Sørensen, eds. Creativity in the Bronze Age: Understanding Innovation in Pottery, Textile, and Metalwork Production Reviewed by Beatriz Comendador Rey

Francesco Iacono. The Archaeology of Late Bronze Age Interaction and Mobility at the Gates of Europe: People, Things, and Networks around the Southern Adriatic Sea Reviewed by Ralph Araque Gonzalez 
Ralph Araque Gonzalez. Intercultural Communications and Iconography in the Western Mediterranean during the Late Bronze Age and the Early Iron Age

Reviewed by Pau Sureda....

Barry Cunliffe and John T. Koch. Exploring Celtic Origins: New Ways Forward in Archaeology, Linguistics, and Genetics

Reviewed by Martín Almagro-Gorbea

Catherine M. Cameron. Captives: How Stolen People Changed the World

Reviewed by Kristian Kristiansen

Guy D. Middleton. Understanding Collapse: Ancient History and Modern Myths

Reviewed by Anthony Smart

Lorna Tilley and Alecia A. Schrenk, eds. New Developments in the Bioarchaeology

of Care: Further Case Studies and Expanded Theory

Reviewed by Marta Díaz-Zorita Bonilla

Doug Bailey. Breaking the Surface: An Art/Archaeology of Prehistoric Architecture

Reviewed by Helen Wickstead 